\title{
WA $\underline{H} D A T A L-W U J U \bar{D}$, PESANTREN, AND RELIGIOUS MODERATION MODEL IN INDONESIA
}

\author{
M. Syamsul Huda \\ UIN Sunan Ampel Surabaya, Indonesia \\ E-mail: m.syamsul.huda@uinsby.ac.id \\ Iqbal Hamdan Habibi \\ UIN Sunan Ampel Surabaya, Indonesia \\ E-mail: iqbalhamdanhabibi@gmail.com
}

\begin{abstract}
This article is based on research on religious moderation in Pesantren (Islamic Boarding School) reviewed from the perspective of Ibn Arabi. It focuses on the violation of belief and religious freedom $(\mathrm{KKB})$ in Indonesia, with its intensity through coercion and subjective judgement against other beliefs and sects. This study aims to engage wahdat al-wujüd, the concept of Ibn Arabi, with the religious moderation concept in pesantren. This study found that (1) the concept of wabdat alwijüd has philosophically constructed moderate mental and mindset; (2) pesantren can instil the concept of religious moderation into students through their educational system, and (3) through wabldat al-wijüd, Ibn Arabi proposes unifying concept and the nature of human being supporting the existence of religious moderation.
\end{abstract}

Keywords: Ibn Arabi; religious moderation; pesantren.

Article history: Received: 11 July 2021; Revised: 30 July 2021; Accapted: 19 August 2021; Available online: 01 September 2021

\section{How to cite this article:}

Huda, Syamsul, and Iqbal Hamdan Habibi. "Wahdat Al-Wujūd, Pesantren, and Religious Moderation Model in Indonesia". Religio: Jurnal Studi Agama-agama 11, no. 2 (2021): 184-202. https://doi.org/10.15642/religio.v11i2.1759 


\section{Introduction}

Diversity is an essential part of life. Thus, as social beings, humans should endeavour tolerance to promote peace as diversity includes character, religion, culture, and even race and ethnicity. On the one hand, religion can play a pivotal role in the unity of society besides race and culture. Yet, on the other hand, it can also trigger worse clashes besides race, culture, and community moral values (integrating force).

Living in harmony is a natural social interaction among individuals and groups with various interests and mutually beneficial needs. The development of technology and media information makes it easier for the community to interact through pages, channels, and social media. However, some need specific efforts to filter data before poor digestion and dissemination so that false news or hoaxes will not harm diversity. Curtis suggested that community has three interaction abilities such as cooperation (affiliation), particularly in problem solving and conflicts (cooperations and revolution conflict), hospitality, attention, compassion (kindness, care and empathetic skills). ${ }^{1}$

Lately, certain parties have used religious symbols ${ }^{2}$ to legitimate acts of violence. Even worse, some used these symbols in activities of different beliefs and religious groups. According to The Wahid Institute, 204 cases with 313 acts of violence in the name of religion occurred in 2016. At the same time, Sugianto argued that the case arose due to differences in beliefs understanding. ${ }^{3}$ Hence, religion was perceived to be no longer an entity to bring peace and harmony ${ }^{4}$ in life. Conversely, they perceived religion as dividing concepts, full of revenge and violence.

Violence in Indonesia is an unfortunate event as it is wellknown for its noble culture with a wide range of diversity in religion,

1 Dan B. Curtis, Business and Professional Communication, 2nd ed. (Dubuque Iowa: Kendall/Hunt, 1997), 70.

2 M. Bilewich and J. Klebaniuk, "Psychological Consequences of Religious Symbols in Public Space: Crucifix Display at a Public University," Journal of Environmental Psychology 35 (2013): 10.

3 Sugianto, "Toleransi Beragama Perspektif Wahdat Al-Wujūd Ibnu Arabi," Indonesian Journal of Islamic Theology and Philosophy 1, no. 2 (2019): 179-94, https://doi.org/10.24042/IJITP.V1I2.5076.

4 W. Zuo'an, "Religious Harmony: A Fresh Concept in the Age of Globalization," Procedia - Social and Behavioral Sciences 77 (2013): 212. 
culture, and traditions. Unfortunately, there is a disruption of diversity. Nevertheless, Indonesia, fortunately, has educational institutions which have empirically instilled concepts of religious moderation through the history of education in the country. The educational institutions are popularly known as pesantren(s) (Islamic boarding schools) with a traditional book study learning base with problematic societal contexts, including religious moderation. ${ }^{5}$ Pesantren also becomes a place to build independent character. ${ }^{6}$

Religious moderation, ${ }^{7}$ especially in Indonesia, can contextually refer to understanding religion as moderate and respectful due to its religious, cultural, and traditional diversity. Therefore, Indonesia has become one of the world's most populous Muslim countries. Islam itself teach how to behave and coexist in diversity. As Fahri suggested, Islam, with its moderate attitude, is very relevant to understand the context of diversity in all aspects: religion, customs, ethnicity, and nation. ${ }^{8}$

Concerning this context, Ibn Arabi (1165-1240 CE), one Muslim Sufi revered in the Islamic tradition as al-shaykh al-akbar (the Greatest Master), ${ }^{9}$ introduced the concept of unity, popularly known as wablat al-wujüd (unity of Being). He stated that there is only one actual Being, namely Allah (The Almighty God). Ibn Arabi's Sufism model eventually expanded from the western part of the Islamic region to the eastern one. ${ }^{10}$ The concept of wablat al-wnjüd itself is Ibn Arabi's most invaluable experience during his spiritual odyssey.

All religions pass on the same vital message, namely peace, goodness, and happiness for humanity. It is in line with what Armia suggested that, from a theological perspective, religion teaches its adherents to create prosperity and promote humanity's wellbeing.

${ }^{5}$ Abdurrahman Wahid, Menggerakkean Tradisi: Esai-Esai Pesantren (Yogyakarta: LKiS, 2001), 4.

6 Masdar Hilmy, "Kepemimpinan Modern Berbasis Karakter Pesantren," The Journal of Islamic Education 7, no. 2 (2019): 89-106.

7 Y. Ganzach, S. Ellis, and C. Gotlibovski, "On Intelligence Education and Religious Beliefs,” Intelligence 41, no. 2 (2013): 124.

8 Mohammad Fahri, "Moderasi Beragama Di Indonesia," Intizar 25, no. 2 (2019): 95-100.

9 M. Raschid, "The Muhyiddin Ibn Arabi Society," Religion 1, no. 16 (1986): 97-99.

10 Abu al-Wafa al-Ghanimi Al-Taftazani, Ibn Sab'in wa Falsafatuh al-Süfiyyah (Beirut: Dar al-Kitab al-Lubnani, 1973), 72. 
Hence, every human being is obliged to make peace for each other's social life. ${ }^{11}$ Nevertheless, complete acceptance of a particular ideology or truth does not mean blaming, vilifying, or even cursing ${ }^{12}$ the reality of others' beliefs. Those certain basic teachings of religion we explored in the specific context of Indonesia's Islamic boarding schools.

This paper discusses the concept of religious moderation in Islamic boarding schools through the concept of wahlat al-wujūd introduced by Ibn Arabi. It used literature research with the descriptive analysis method ${ }^{13}$ in analyzing the topic. This concept is in line with ta'wil method used by Ibn Arabi for his philosophical Sufism, which he perceived as a legitimate extension of the Qur'an, from one context to another. Ibn Arabi and al-Ghazali and other theologians had insightful discussions on the use of $t^{\prime}$ wil $^{14}$ despite its difference from the Monists. The Monists refer to the relationship between outer and inner meaning. Al-Ghazali's did not take into account this concept in his Qur'anic exegesis. Corbin states that ta'wil, hermeneutics ${ }^{15}$, confirmed prophetic revelation with the coming of Prophet Muhammad, the seal of prophethood. He postulates that prophetic hermeneutics does not conclude and will continue to reveal the hidden meaning until the "return", the parousia.

According to the concept of wabdat al-wujüd, humanity is obliged to create a harmonious life. This concept is a fundamental teaching in the world of Sufism, and thus Ibn Arabi was eventually entitled as shaikh al-akbar (the great teacher). He showed a systematic, broad and profound description of his thought on Sufism that is distinct from

11 Armia, "Kesatuan Agama-Agama Dan Kearifan Perenial Dalam Perspektif Tasawuf," At-Tahrir Jurnal Pemikiran Islam 13, no. 1 (2013), 127:149. https://doi.org/10.21154/al-tahrir.v13i1.10.

12 Harry C. Triandis, "Toward Understanding Violence in Islam," Acta de Investigación Psicológica 3, no. 1 (April 1, 2013): 972. https://doi.org/10.1016/S2007-4719(13)70946-3.

13 John W. Creswell and J. David Creswell, Research Design: Qualitative, Quantitative, and Mixed Methods Approaches (Thousand Oaks, California: Sage Publications, 2018), 150.

14 W. Rahmah, "Pemikiran Al-Raghib Al-Asfahani Tentang Al-Qur'an, Tafsir Dan Ta'wil," Cakrawala: Jurnal Manajemen Pendidikan Islam Dan Studi Sosial 4, no. 2 (2020): 169-191.

15 O. Rosenqvist, "Deconstruction and Hermeneutical Space as Keys to Understanding the Rural," Journal of Rural Studies 15, no. 1 (2020): 7. 
the previous Sufi concept. The teachings of Ibn Arabi look at the existence of God, nature and humanity as a unity, and God represents everything in existence. Thus, what exists becomes relatively existent; something existed by none other than the one who has made it alive. Therefore, as what exists represents His existence and everything that exists originates from Him, He becomes the Essence of everything.

However, the existent and the finite one does not mean that it becomes infinite. It also does not mean that the universe and humanity become God and vice versa. Even though God, the universe and humanity are considered different in one existence or wablat al-wujüd, the universe and humankind are relative and finite. Their existence depends on the Infinite. Whereas God the infinite exists beyond the relationship, not the one covered in understanding and feeling. God is independent of all His creatures. His existence is not from outside Himself and not even because of others beyond Himself. Yet, God exists because of Himself and by Himself. He covers all that He created.

With all that He created, it concerns His lordship. Without His creatures, He will not be known as God. The object of worship (ilah) to the malūh (logical complement of ilab) is eventually identified. Thus, Ibn Arabi thought of the reality of nature and humanity as nothing other than divine tajalli and a mirror to see His Most Perfect Self. Likewise, as the knowledge of His existence. This is also the purpose of His creation

Ibn Arabi also discussed the top state of his asceticism. ${ }^{16} \mathrm{He}$ wrote that "You, thus, will see all your actions belong to Him and all your attributes become His attributes and Essence. You become His Essence. You do not become Him, or He becomes you, either in the greatest or the least degree. Everything perishes but His face, i.e., nothing exists but His face, then you wither, only God's Face exists." ${ }^{17}$

The primary sources used in this article include al-Futūhät alMakkiyah ${ }^{18}$ and Fus ūs al- $\underline{\text { Hikeam. }}{ }^{19}$ Both books reveal many of Ibn

16 C. Adair-Toteff, "Asceticism," in International Encyclopedia of the Social \& Behavioral Sciences, 2015, 60-64.

17 David P. Brewster, "The Study of Sufism; towards a Methodology," Religion 6, no. 1 (1976): 31-47.

${ }_{18}$ Ibn Arabi, Al-Futūhāt al-Makekiyyah, 8th ed. (Beirut: Dar al-Fikr, 2002).

19 Ibn Arabi, Fuṣūṣ al-Hikeam (Beirut: Dār al-Kitāb al-'Arabī, 1980). 
Arabi's thoughts on philosophical Sufism. In addition, these books are monumental and full of logical use in ta'wil.

\section{Religious Moderation}

The word moderation comes from Latin moderatio, which means neither excess nor deficiency. ${ }^{20}$ Therefore, moderation is also commonly referred to as moderate, which means balance in terms of beliefs, morals, and human character. Fahri refers to the word moderation through the use of Arabic words, wasatiyyah, which means the centre of two borders, fair or standard. ${ }^{21}$

In Arabic terms, the one who practices wasatizyah is called wasit, perceived as having several roles such as mediator and intermediary. For example, wasit can mediate between two separate people or groups in the dispute or those involved in a disagreement to help them agree or find a solution to their problems. As Fahri suggested, the best of everything is the neutral or being in the middle position. For instance, there is a word called generous between stingy and extravagant. Also, there is a word called brave between cowardice and reckless.

The implementation of moderation in Islam can be divided into several discourses; (1) moderation of belief and faith; (2) moderation of worship; (3) moderation of behaviour and manners; (4) moderation concerning religious law. The concept of religious moderation will eventually be achieved through understanding and having a moderate attitude. Therefore, Muslims should start the teaching and learning of moderate attitudes at an early age.

In terms of educational tradition, Indonesia has a specific and unique educational system, having long been practised in pesantren which has instilled moderate Islamic values into santri (Muslim student) and society for ages. As Edi Junaedi suggested, pesantren is an educational institution to fulfil Muslim characteristics in terms of ummatan wasatan. Hence, the concept of wasatiyah can make all the difference in dealing with a wide range of different opinions amidst socio-cultural differences in Indonesia. ${ }^{22}$

${ }^{20}$ Kementerian Agama, Moderasi Beragama (Jakarta: Kementerian Agama, 2019), 15.

${ }^{21}$ Fahri, "Moderasi Beragama Di Indonesia," 95-100.

${ }^{22}$ Edi Junaidi, "Inilah Moderasi Beragama Perspektif Kementerian Agama," Jurnal Harmoni 18, no. 2 (2018): 184. 
Pesantren becomes the prototype of religious-moderation implementation. ${ }^{23}$ Ali Nurdin testified that a particular kyai of one pesantren in Central Java always provides the class with a discussion of current events in the society in which religious moderation becomes the trending topic. ${ }^{24}$ Moreover, most pesantren in Indonesia belong to the ideology of abl al-sunnah wa al-jamäah, which provide the students with basic knowledge of moderate Islamic teachings. Furthermore, the kyais - with their positive attitude, behaviour, and manners-become the role models for the students in their daily lives. This phenomenon indicates that Islam can live together with people of other religions and accept all differences.

\section{Ibn Arabi and Wahdat al-Wujūd}

The differences in life imply unity. The attitudes of defamation, blasphemy, even blame for disagreements do not reflect religious teachings. In the concept of wablat al-wujüd, humanity has a solid mandate to maintain peace and harmony in life.

Ibn Arabi is renowned among both Muslim and non-Muslim scholars, at least for two reasons. Firstly, he has been used as a role model and has won admiration for his genius in knowledge, science, and spirituality. Secondly, Ibn Arabi was popularly known as a controversial scholar. He proposed anti-mainstream teachings compared to traditional religious doctrines in general. Panji Maulana testified that Ibn Arabi became one of the magnets in Islamic studies, especially in Sufism. ${ }^{25}$ Scholars have discussed his life journey, experiences, thoughts, and the initial process of becoming a Sufi.

Ibn Arabi was born in Murcia, Southeast Andalusia (Spain) in $560 \mathrm{H}$ or around $1163 \mathrm{CE}$. He came from a religious family in Tayy, the Arabian tribe. His father and his uncle were also Sufis. At the age of 8, Ibn Arabi left for Lisbon to get Islamic education. He obtained knowledge of the Koran and figh from Shaykh Abu Bakr ibn Khalaf. Ibn Arabi spent 30 years studying hadith, kalam, and fiqh in Sevilla, the Sufi centre of Andalusia. He also visited some areas, such as

${ }^{23}$ Khairurrijal, "Eksistensi Pondok Pesantren Di Tengah Kemodernan Pesantren," El -Hekam 4, no. 2 (2020): 114-17, bttps:// doi.org/10.31958/JEH.V4I2.2013.

24 Ali Nurdin, "Model Moderasi Beragama Berbasis Pesantren Salaf," Jurnal Islamica 14, no. 1 (2019): 82-102.

${ }^{25}$ Moh. Panji Maulana, "Filsafat Ketuhanan Ibn Arabi; Telaah Kitab Hill AlRumuz Wa Mafatih Al-Kunuz," Yaqzhan 4, no. 2 (2018): 330-349. 
Cordoba, where he met Ibn Rushd, and both eventually became best friends. Ibnu Arabi also learnt some of Ibn Masarra's works, one of which discussed purifying lights.

In 1194 CE Ibn Arabi studied at Sufi school in Tunisia, where he learnt Ibn Qoyi Khal'an Na'layn's work. Abdul Halim Rofii quoted Ibn Khaldun (1332-1406 CE) as suggesting that the work of Ibn Qoyi should be burned and all his ideas should be dismissed. ${ }^{26}$ Through his works, Ibn Khaldun also indicated that Ibn Qoyi refers to the elements of bid'ah (heresy).

When making a pilgrimage to Mecca in $1201 \mathrm{CE}$, Ibn Arabi fell in love with a beautiful, young, clever daughter of a shaykh. He eventually wrote a composition known as Turjumàn al-Ashwāq (The Translation of Longing for Love). He wrote the manuscript in standard classical Arabic rules interpreted mystically and imaginatively. It seems to be a conversation between him and his loved one. Ibn Arabi eventually continued his journey to Cairo, Konya, Baghdad, and Damascus as the last place until he passed away.

As a great Muslim thinker, his thought influenced many European scholastics and one of the most well-known European thinkers, Dante. ${ }^{27}$ Asin Palacios confirmed that Ibn Arabi's thoughts also influenced Eastern and Western Sufis and mystics. ${ }^{28}$ There are twelve works of Ibn Arabi which Ahmad Bangun Nasution successfully codified. ${ }^{29}$ The most phenomenal pieces of Ibn Arabi are al-Futūhäat al-Makkiyah and Fus us s al-Hikam. Muhammad Parsya analogizes Futū $\underline{b} \bar{t}$ as the heart and Fusüs as the soul. This analogy is based on Ibn Arabi's statement that an angel of inspiration dictated Futūhät under God's instruction.

Whereas, Fusūus is a work consisting of twenty-nine chapters on the science of prophecy, inspired by the Prophet. ${ }^{30}$ In line with Harun

26 B.A.S Dajani, "The Ideal Education in Ibn Khaldun's Muqaddimah," Procedia - Social and Behavioral Sciences 192 (2015): 309.

27 Al-Taftazani, Ibn Sab'in wa Falsafatuh al-Süfiyyah, 201.

28 Abdul Halim Rofi'ie, "Wahdat Al Wujud Dalam Pemikiran Ibnu Arabi," Jurnal Ulul Albab 13, no. 2 (2010): 131-41.

${ }_{29}$ Ahmad Bangun Nasution, Akblak Tasawnf: Pengenalan, Pemahaman, Dan Pengaplikasiannya (Jakarta: Rajawali Press, 2013), 145.

30 Annemarie Schimmel, Mystical Dimension of Islam (Chapel Hill: The University of North Carolina Press, 2011), 273. 
Nasution's opinion that Fusūs al- $\underline{H}$ ikam was taken entirely from Ibn Arabi's dream with the Prophet Muhammad in $626 \mathrm{H}$ in Damascus. ${ }^{31}$ It discusses human and spiritual natures taken from the experiences of certain prophets. This work eventually became famous as many poets liked and developed it.

Wabdat al-wujüd might interpret that there is only One Being, and this universe is the manifestation of the One, Allah, God the Almighty. Yusuf Musa simplified $W a \underline{h} d a t$ al-wrijūd as a specific concept stating là maujüda illā al-wujūd al-wähidid, which means nothing and no one exists except The One. Though The One also belongs to a number does not make Him numbered in the Essence. For instance, humanity is indeed many, but in fact, they refer to one kind. ${ }^{32}$

In the concept of wabdat al-wujüd, everything that exists has two sides to its nature. The first is the external nature which refers to the nature of the created (creatures), and the second is the inner nature which refers to the nature of the creator (divinity). The universe represents God. Thus, humanity can see God through the universe. Moreover, God looks at the universe to see Himself as every single object has a divine nature. What appears in the universe comes from The Only One, though it seems many in appearance. Thus, that is the way the understanding of unity comes out.

Harun Nasution suggested that God created all creatures, and their existence depended on God's decision. Therefore, if God had no chance to exist, then everything beyond God would not exist. Thus, the one who has an actual existence is only God, and every created existence essentially depends on God's presence. Hence, there is only one existence that is the existence of God and others beyond God is merely the reflection of God. ${ }^{33}$

According to Zainun Kamal, Ibn Arabi inserted that there is only one absolute being in the form of three concepts: abädiyah, wahidiyah, and tajalli shubüdì.

In the concept of abadiyah (One God), the existence of God is an absolute, nameless, and traits Essence. Therefore, the state of being pure and unconditional attach to God. God is also beyond

31 Harun Nasution, Filsafat Dan Mistisisme Dalam Islam (Jakarta: Bulan Bintang, 1973), 92.

${ }^{32}$ Muhammad Yusuf Musa, Falsafah al-Akhläq fì al-Isläm wa Silatubā bi alFalsafah al-Iqriqiyyah (Cairo: Muassasah al-Kanji, 1963), 248.

${ }^{33}$ Nasution, Filsafat Dan Mistisisme Dalam Islam, 95. 
before and after, above or below, how or where, and not even when. In the concept of wabidiyah, the Essence manifests through nature and name. Hence, the name of Allah eventually came to unify nature and the name. Finally, the concept of tajalli shubüdi means that Allah appears through His name and attributes in empirical reality. ${ }^{34} \mathrm{By}$ this concept, diversity and unity are part of world view in life.

Having different religions do not mean to blame or even justify a particular belief. Every religion teaches the same values to humanity. According to Sugianto, every religion brings its adherents to their primary and essential origin: God the Almighty. ${ }^{35}$ The question is: could it be possible to unify all religions? Religious unity will likely come to reality when contacted with the esoteric, transcendent, and spiritual realms. That particular state can only be manifested with one symbolic intuition called religion, so it is subjective and exclusive.

For that reason, people of all religions should put a wise stance in dealing with religious differences. Recent chaos among religious believers is not due to inappropriate teaching in religions but is caused by different points of view and inappropriate responses towards disagreements. Religion is the house of peace. Yet, unfortunately, due to some individual behaviours, religion has become a premier institution in public, and thus, some violence took place in the name of religion. Therefore, Ibn Arabi brought a profound discussion on human nature.

\section{Ibn Arabi and the Nature of Human Being}

According to Ahmad Kholil, Essence is static, unchanging, and essential: it causes something as it is and is even different from others. ${ }^{36}$ Concerning human nature (Essence), it is the process to understand the permanent and unchangeable Essence or reality of humankind: to identify their distinctive points compared with other creatures. Human nature in philosophy indicates a pre-existent understanding of being human. The Essence counts more than

34 Haidar Putra Daulay, Zaini Dahlan, and Chairul Azmi Lubis, "Takhalli, Tahalli Dan Tajalli," Pandawa Jurnal Pendidikan Dan Dakwah 3, no. 3 (2021): 385, https://doi.org/10.36088/pandawa.V3I3.1334.

35 Sugianto, "Toleransi Beragama Perspektif Wahdat Al-Wujūd Ibnu Arabi," 179-94.

36 Ahmad Kholil, "Manusia di Muka Cermin Ibn Arabi," Jurnal El-Harakah 8, no. 3 (2006): 373-85. 
existence. Therefore, classical and medieval philosophy put humans as an essential object of discussion.

Yasir Nasution confirmed that in the next period, humans were redefined and no longer had a permanent characteristic. ${ }^{37}$ Instead, humans are considered to be historical creatures due to their histories compared to other creatures. In other words, humans can be understood through all their experiences or journeys as they have growing impulses and orientations in themselves. Thus, two different orientations come up: classical and modern philosophy. Classical philosophy views the Essence of human beings, while modern philosophy argues that humans depend on their historical or anthropological stance.

In the light of Islam, QS al-Tin stated that human is the best work of God. Therefore, human is in the highest position of all God's creation. However, to reach their point of perfection, humans need to empower their potentials. Otherwise, they will likely be in a shallow position at which, as Ahmad Kholil stated, humans will be equally located to other creatures. ${ }^{38}$ Therefore, to reach the point of perfection, humans must return to God with faith and piety.

Around the $13^{\text {th }}$ century, Ibn Arabi proposed his idea called alinsan al-kamil. It is the ideal concept of looking at the human being as the locus of God's existence. Previously, similar terms came up such as al-wali al-kāmil initiated by Abu Yazid al-Busthami, nūr Mubammadī and al-bulül by al-Hallaj, ${ }^{39}$ and the concept of khatam al-awliyy $\bar{a}$ ' by alHakim Tirmidzi. ${ }^{40}$ Related to human (humanity) elements, Ibn Arabi proposed two aspects, namely al-baqq and al-kbalq. ${ }^{41}$ The element of al-baqq is identical to the substance or jawhar according to Ash'ari theology, while the aspect of al-khalq refers to the earth. The two elements arose from the response of logical reasoning that all realities

37 Yasir Nasution, Manusia Menurut Al-Ghazali (Jakarta: Rajawali Press, 1988), 50.

38 Kholil, "Manusia di Muka Cermin Ibn Arabi," 373-85.

39 Uril Babruddin, "Musykilah Ta'limiyah Al-Lughah Al-'Arabiyah Bi Jami'Ah Maulana Malik Ibrabim Malang Wa Al-Hulul Al-Muqtarahah Laba," Lingua Jurnal Ilmu Bahasa Dan Sastra 12, no. 1 (2017): 22.

${ }^{40}$ Yunasril Ali, Manusia Citra Ilabi (Jakarta: Paramadina, 1997), 8.

${ }^{41}$ Aly Mashar and Nailal Muna, "Filsafat Etika Tasawuf Syaikh 'Abdul Qadir Al-Jailani: Kajian Etika Salik Dalam Kitab Ghunyat Li Thalibi Thariq AlHaqq," Intelektual: Jurnal Pendidikan Dan Studi Keislaman 10, no. 3 (2020): 283, https://doi.org/10.33367/JI.V10I3.1427. 
refer to one.

The real world or multiple empirical nature, according to Ibn Arabi, is the media of God's existence and attribute, which is perceived as an inner aspect as it is merely imaginative though with the true Essence of God. In contrast, the universe was created as God wanted to see Himself through His creatures. Therefore, the limitation of the universe and God's majesty is that the universe cannot perfectly accommodate God's Essence and attributes. For that reason, the concept of al-insān al-kamil comes up to make the Essence and attributes of God perceptibly perfect.

Nür Mubammadì (also known as al-haqiqah al-Mubammadiyah) becomes the perfect media for God's tajalli to manifest Himself. Nür Mubammadi was the first creature even before Adam-the first man in the world-was created. Ibn Arabi also called Nūr Muhammadi as al'aql al-awwal and al-qalam al-a'là as it becomes the only cause for the creation and maintenance of any other creatures in the universe. Yunasril Ali confirmed the symbol of God's eternal and infinite knowledge is the "first reasoning" based on the nature of Muhammad. In addition, the qalam or pen symbolizes God's writing instrument in which "ink" became the symbol of spirit in the form of potentials. The writing "letters" signified the shape of the universe. ${ }^{42}$

In other words, al-insān al-kamil became the prototype of God's existence through His tajalli in the universe. The Essence of God is reflected in the core of al-insān al-kamil. His soul reflects nafs alkulliyah, His body is reflected from the throne, and his heart is related to bait al-ma'mūr. As Ahmad Kholil quoted, Ibn Arabi stated that alinsān al-kamil refers to a perfect human being, both in form and knowledge. The perfection of existence is the highest manifestation of God's presence. In terms of knowledge, perfection means reaching the highest level of consciousness by realizing the unity of God's Essence called ma'rifah. ${ }^{43}$

In response, Ibn Arabi and other sufis suggested that to achieve ma'rifah as the highest philosophical position, one must first conduct

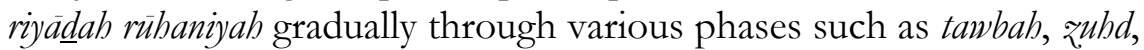
wara', sabr, tawakkal, and rida. . Whereas moving from one position to another is determined by one's maturity, self-management, and being fully aware of that particular position. Furthermore, the top position

42 Ali, Manusia Citra Ilabi, 56.

43 Kholil, "Manusia Di Muka Cermin Ibn Arabi," 373-85. 
expected by people is the ultimate truth called maqaim al-ma'rifah. Therefore, ma'rifat should begin with knowing and realizing one's true identity. When one knows their true self, they will know God.

When related to human character, especially religion, Ibn Arabi suggested that the al-insann al-kamil will first form good mindsets, better attitudes, and growing motivation. Consequently, all those qualities should be nurtured at an early age. Hence, with a good mindset, they will be able to dynamize and adapt over time so that insightful horizons and noble moral values will likely come alive. Moreover, when the horizon has been formed, the soul will likely grow. Instincts will then be directed based on one's understanding. When some understand and comprehend the creed ('aqidab), as Sugianto stated, the soul will bear a moderate attitude and respect others and will be able to live together in harmony despite diversity.

\section{Religious Moderation in Pesantren}

After discussing the concept of wabdat al-mujüd of ibn Arabi, we want to see how the concept can be implemented in Indonesia's attitude of religious moderation through pesantren education. Pesantren already has the capital to run a moderation-based education system. We found it at least in three points. First, the culture and tradition of literacy on various fields of Islamic science such as figh (Islamic jurisprudence), tasawnuf (sufism), badith (the Sunna), and tafsir (Qur'anic exegesis). In these references, students will at least be accustomed to dealing with Muslim scholars' differences of opinion.

The books that santri deal with in pesantren, for example, includes Mażābib al-Arba'ah (Islamic law in four sects of Islam), Kitāb al-Umm (al-Imām al-Shāfi'î), Bidāyah al-Mujtabid (Ibn Rushd), alMuqaddimah al-Hadramiyyah ('Abdullah ibn Abdul Karim Bafadhal), Tafsì ibn Katsir, Tafsir Jalalayn, and Tafsì Khärin (the book of Ali ibn Muhammad ibn Ibrahim al-Sihhī al-Baghdadī). There are also several books of Sufism such as I hyyà' 'Ulümuddin (al-Imām al-Ghazāili), alHikam (Ibn 'Ataillah), Risālah al-Mustarshidīn (Harīth al-Muhāsibì), and the book of Adab al-Nufüs. These books are an essential element of the pesantren curriculum. In fiqh, for example, some teachings explicitly teach the values of tolerance. ${ }^{44}$

The second point is the diversity of santris cultural, ethnic,

44 Syamsun Ni'am, "Pesantren: The Miniature of Moderate Islam in Indonesia," Indonesian Journal of Islam and Muslim Societies, 5.1 (2015): 127. 
language, and traditional background. In this diverse milieu, santri can directly practice tolerance to build a harmonious life. This has been made possible with the availability of the classical Islamic references that have been mentioned. As a result, students can respect, understand, and learn different aspects of each other's culture. Although the potential for conflict is still likely to occur, the santri will also learn how to build peace and conduct conflict resolution. In this situation, santri can learn and practice the concept of ummatan wabidah and ummatan wasatan as the initial basis of growing a moderate attitude.

In addition, this diverse environment can also make santri understand and experience that diversity is inevitable. Hence, they will get used to differences of opinion and attitude. In this situation, the role of pesantren can be an enabler to cultivate equal dialogue in solving their problems, especially related to differences in identity and interest. The concept of religious moderation itself has become the foundation of how every Muslim should behave towards diversity. The concept of ummatan wasatan found in the Qur'an can be implemented on the behaviour of the creed ('aqidah), sharia, and Sufism. ${ }^{45}$ In this context, the concept of wabdat al-wujūd can be used as a philosophical and ideological basis in instilling the values of tolerance.

The third point is to make kiai an example of religious moderation and a modest life practice. Although we are aware that not all kiai practice ascetic living, their role is essential in instilling an attitude of religious moderation. This role applies not only to the community in the pesantren, but also to the general public. Using "biopower" in moral and intellectual transmission to learners has also been a testament to how direct examples of moral ethics can be effectively carried out by students and society. ${ }^{46}$ At this point, the role of kyai is important in maintaining the teachings and methods of

45 Achmad Yusuf, "Moderation of Islam in the Dimensions of the Islamic Trilogy (Creed, Sharia, and Sufism)", AL MURABBI: Journal of Islamic Religious Education, Vol. 3, No. 2 (2018), 203-216.

46 Lailiyatul Azizah, "Portraits of Religious Moderation in the Salaf Pesantren Education System in Indonesia," Jurnal Pendidikan Islam, 10.1 (2020): 27. 
Walisongo's legacy to practice tolerance and respect for local cultures. ${ }^{47}$ During this time, kyai has also been a figure who provides a direct example in teaching inclusive and peaceful attitudes towards others. ${ }^{48}$ This role will be capital in promoting attitudes of moderation in pesantren.

These three points are the practical value of how religious moderation can be implemented in the pesantren education system. Through the concept of wabdat al-wujüd, Muslims are generally taught to practice moderate Islam by improving the quality of life through education that accommodates differences. The emphasis on the value of unity in these implementation points can be internalized through the teachings of Ibn Arabi Sufism. First, the realization that the Essence of God is absolute but can be present in a diverse form. Second, the realization that man is a manifestation (tajalli) of God who has the potential to become al-insān al-kamil. Third, in achieving the process of becoming an al-insān al-kämil, Muslims can practice riyädah rühaniyah such as tawbah, zubd, wara', sabr, tawakkal, and rida, attitudes that have been used as curriculum in pesantren.

Pesantren has become evident as a place that accommodates differences and manages conflict ${ }^{49}$ and anticipates radical understanding. ${ }^{50}$ Through an education system that advocates peace and moderate values, pesantren can be a place to realize the cultivation of inclusive attitudes to its learners. Internalization of the importance of peace, moderate attitudes, and multiculturalism has been going on throughout the history of the establishment of

47 Titis Thoriquttyas and Farida Hanun. "Amplifying the Religious Moderation from Pesantren: A Sketch of Pesantren's Experience in Kediri, East Java," Analisa: Journal of Social Science and Religion 5.02 (2020): 221. See also, Syamsun Ni'am. "Pesantren: the Miniature of Moderate Islam in Indonesia," 119.

48 Titis Thoriquttyas and Farida Hanun, "Amplifying the Religious Moderation," 222.

49 Titis Thoriquttyas, "Amplifying the Religious Moderation from Pesantren," 221; Syamsun Ni'am, "Pesantren: The Miniature of Moderate Islam in Indonesia," 124.

50 Ali Nurdin and Maulidatus Syahrotin Naqqiyah, "Model Moderasi Beragama Berbasis Pesantren Salaf," Islamica: Jurnal Studi Keislaman, 14.1, (2019): 89. 
pesantren in Indonesia. $^{51}$

\section{Conclusion}

Religious moderation in the Islamic perspective can be divided into four aspects: moderation in creed, worship, ethics, and sharia or Islamic law. As an influential Islamic education based in Indonesia, pesantren can apply the values of religious moderation through its education curriculum system. By building an education system based on religious moderation, educators and learners will be accustomed to facing differences in attitudes, opinions, and outlook on life. They will also learn firsthand how to prevent conflict and establish a peaceful dialogue.

Since pesantren made classical Islamic literature the primary reference in producing Islamic law and building the values of tolerance, they can make the concept of wahdat al-wujud Ibn Arabi a philosophical and ideological basis in forming a mindset and mentality that can give birth to a moderate attitude. Furthermore, the concept of unity and human nature is very suitable to support the creation of religious moderation through the internalization of these values to the santri and the surrounding community. Thus, pesantren can keep the importance of religious moderation in the literature level and encourage the practice of religious moderation with diversity that lives in it.

Through his concept of wablat al-wujüd and the study of human nature, Ibn Arabi had a good impact on the formation of human character (manners and behaviour). Humans (humanity) will go through the construction of mindsets, attitudes, and motivation. The mindset properly formed will likely be dynamic and adaptive over time. Hence, one will be led to a good attitude, respect others, and live together in harmony despite diversity.

\section{References}

Adair-Toteff, C. "Asceticism." International Encyclopedia of the Social \& Behavioral Sciences, 2015.

Azizah, Lailiyatul. "Portraits of Religious Moderation in the Salaf Pesantren Education System in Indonesia." Jurnal Pendidikan Islam, 10.1 (2020): 18-32.

51 Syamsun Ni'am, "Pesantren: The Miniature of Moderate Islam in Indonesia," 125. 
Achmad Yusuf, "Moderation of Islam in the Dimensions of the Islamic Trilogy (Creed, Sharia, and Sufism)", AL MURABBI: Journal of Islamic Religious Education, Vol. 3, No. 2 (2018): 203216.

Al-Taftazani, Abu al-Wafa al-Ghanimi. Ibn Sab'in Wa Falsafatub Al Shufiyyah. Beirut: Dar al Kitab al Lubnani, 1973.

Ali, Yunasril. Manusia Citra Ilabi. Jakarta: Paramadina, 1997.

Arabī, Ibn. Al-Futühāt Al-Makkiyyah. 8th ed. Beirut: Dar al-Fikr, 2002. Arabī, Ibn. Fușūs Al-Hikeam. Beirut: Dār al-Kitāb al-'Arabī, 1980.

Armia. "Kesatuan Agama-Agama Dan Kearifan Perenial Dalam Perspektif Tasawuf." At-Tabrir Jurnal Pemikiran Islam, 13, no. 1 (2013).

Bahruddin, Uril. "Musykilah Ta'limiyah Al-Lughah Al-'Arabiyah Bi Jami'Ah Maulana Malik Ibrahim Malang Wa Al-Hulul AlMuqtarahah Laha." Lingua Jurnal Ilmu Bahasa Dan Sastra 12, no. 1 (2017).

Bilewich, M., and J. Klebaniuk. "Psychological Consequences of Religious Symbols in Public Space: Crucifix Display at a Public University." Journal of Environmental Psychology 35 (2013).

Brewster, David P. "The Study of Sufism; towards a Methodology." Religion 6, no. 1 (1976): 31-47.

Busyro, Aditiya Hari Ananda, and Tarihoran Sanur Adlan. "Moderasi Islam (Wasathiyyah) Di Tengah Pluralisme Agama Indonesia." Jurnal Fuaduna: Jurnal Kajian Keagamaan Dan Kemasyarakatan 3, no. 1 (2019): 1-12. https://doi.org/10.30983/FUADUNA.V3I1.1152.

Creswell, John W., and J. David Creswell. Research Design: Qualitative, Quantitative, and Mixed Methods Approaches. California: Sage Publications, 2018.

Curtis, Dan B. Business and Professional Communication. 2nd ed. Dubuque, Iowa: Kendall/Hunt, 1997.

Dajani, B.A.S. "The Ideal Education in Ibn Khaldun's Muqaddimah." Procedia - Social and Behavioral Sciences, 192 (2015).

Daulay, Haidar Putra, Zaini Dahlan, and Chairul Azmi Lubis. "Takhalli, Tahalli Dan Tajalli." Pandawa Jurnal Pendidikan Dan Dakwah, 3, no. 3 (2021): 348-65. https://doi.org/10.36088/pandawa.V3I3.1334.

Fahri, Mohammad. "Moderasi Beragama Di Indonesia." Intizar 25, no. 2 (2019): 95-100. 
Ganzach, Y., S. Ellis, and C. Gotlibovski. "On Intelligence Education and Religious Beliefs." Intelligence, 41, no. 2 (2013).

Hilmy, Masdar. "Kepemimpinan Modern Berbasis Karakter Pesantren." The Journal of Islamic Education, 7, no. 2 (2019): 89106.

Junaidi, Edi. "Inilah Moderasi Beragama Perspektif Kementerian Agama." Jurnal Harmoni, 18, no. 2 (2018).

Kementerian Agama. Moderasi Beragama. Jakarta: Kementerian Agama, 2019.

Khairurrijal. "Eksistensi Pondok Pesantren Di Tengah Kemodernan Pesantren." El -Hekam, 4, no. 2 (2020): 113-28. https://doi.org/10.31958/JEH.V4I2.2013.

Kholil, Ahmad. "Manusia Di Muka Cermin Ibn Arabi." Jurnal ElHarakah, 8, no. 3 (2006): 373-85.

Mashar, Aly, and Nailal Muna. "Filsafat Etika Tasawuf Syaikh 'Abdul Qadir Al-Jailani: Kajian Etika Salik Dalam Kitab Ghunyat Li Thalibi Thariq Al-Haqq." Intelektual: Jurnal Pendidikan dan Studi Keislaman, 10, no. 3 (2020): 272-86. https://doi.org/10.33367/JI.V10I3.1427.

Maulana, Moh. Panji. "Filsafat Ketuhanan Ibn Arabi; Telaah Kitab Hill Al-Rumuz Wa Mafatih Al-Kunuz." Yaqzhan, 4, no. 2 (2018): 330-49.

Musa, Muhammad Yusuf. Falsafah Al Akblaq Fi Al Islam Wa Shilatuba Bi Al Falsafah Al Iqriqiyyah. Cairo: Muassasah al-Kanji, 1963.

Nasution, Ahmad Bangun. Akblak Tasawnf: Pengenalan, Pemahaman, Dan Pengaplikasiannya. Jakarta: Rajawali Press, 2013.

Nasution, Harun. Filsafat Dan Mistisisme Dalam Islam. Jakarta: Bulan Bintang, 1973.

Nasution, Yasir. Manusia Menurut Al-Ghazali. Jakarta: Rajawali Press, 1988.

Nurdin, Ali. "Model Moderasi Beragama Berbasis Pesantren Salaf." Jurnal Islamica, 14, no. 1 (2019): 82-102.

Ni'am, Syamsun. "Pesantren: the miniature of moderate Islam in Indonesia." Indonesian Journal of Islam and Muslim Societies, 5.1 (2015): 111-134.

Rahmah, W. "Pemikiran Al-Raghib Al-Asfahani Tentang Al-Qur'an, Tafsir Dan Ta'wil." Cakrawala: Jurnal Manajemen Pendidikan Islam Dan Studi Sosial, 4, no. 2 (2020).

Raschid, M. "The Muhyiddin Ibn Arabi Society." Religion, 1, no. 16 
(1986).

Rofi'ie, Abdul Halim. "Wahdat Al Wujud Dalam Pemikiran Ibnu Arabi." Jurnal Ulul Albab, 13, no. 2 (2010): 131-41.

Rosenqvist, O. "Deconstruction and Hermeneutical Space as Keys to Understanding the Rural." Journal of Rural Studies, 15, no. 1 (2020).

Schimmel, Annemarie. Mystical Dimension of Islam. Chapel Hill: The University of North Carolina Press, 2011.

Sugianto. "Toleransi Beragama Perspektif Wahdat Al-Wujūd Ibnu Arabi." Indonesian Journal of Islamic Theology and Philosophy, 1, no. 2 (2019): 179-94. https://doi.org/10.24042/IJITP.V1I2.5076.

Triandis, Harry C. "Toward Understanding Violence in Islam." Acta de Investigación Psicológica, 3, no. 1 (April 1, 2013): 969-85. https://doi.org/10.1016/S2007-4719(13)70946-3.

Thoriquttyas, Titis, and Farida Hanun. "Amplifying the Religious Moderation from Pesantren: A Sketch of Pesantren's Experience in Kediri, East Java." Analisa: Journal of Social Science and Religion, 5.02 (2020): 221-234.

Wahid, Abdurrahman. Menggerakkan Tradisi: Esai-Esai Pesantren. Yogyakarta: LKiS, 2001.

Zuo'an, W. "Religious Harmony: A Fresh Concept in the Age of Globalization." Procedia - Social and Behaioral Sciences, 77 (2013). 